UDK: 343.851(437.6)

Pregledni rad

\title{
IDENTITY OF THE CURRENT ISSUES RELATED TO DETECTION AND CLARIFICATION OF JUVENILE CRIMES IN THE SLOVAK REPUBLIC
}

\author{
Monika Hullova ${ }^{1}$ \\ Criminal Police Department of the Academy of the Police Force \\ in Bratislava
}

\begin{abstract}
Summary: The study deals with theoretical and practical aspects of the fight against juvenile delinquency in the Slovak Republic, i.e. with detection and clarification (investigation) of these types of crimes, i.e. crimes committed by minors and youth. The author analyses the current situation in the field of violent crime, crime against morality, property crime, other general crime, economic crime, and environmental crime, whilst also uses and analyses criminal statistical data. One part of the study brings the results of a research (through questionnaire survey) which has been conducted in the police by the members of the Criminal Police Department of the Academy of the Police Force in Bratislava.
\end{abstract}

Keywords: youth, a minor, juvenile crime, juvenile delinquency, a child, a juvenile offender, a young offender, young adult, violent crime, crime against morality, general crime, economic crime, environmental crime, detection, clarification, investigation

\section{Introduction}

Juvenile crime (juvenile delinquency, juvenile offending or youth crime) is a summary term used for crimes committed by a person under the age of 18 . According to the Slovak criminal law "a minor" is a person under the age of 18 unless they have reached the legal age (majority) earlier (e.g. by entry into marriage). Apart from that it is necessary to distinguish between a "child" (a

1 JUDr. Monika HULLOVÁ, PhD, E-mail: monika.hullova@minv.sk. 
person who, at the time of commission of the criminal offence, is younger than 14 years of age), "juvenile or young offender" (a natural person who, at the time of commission of the criminal offence, is over 14 and under 18 years of age), and " $a$ young adult" (a person who is between 18 and 21 years old).

Moreover, a definition of this age-group can be found in the Slovak legislation:

- Act No 311/2001 the Labour Code (uses the term "juvenile employee" - an employee under the age of 18),

- Act No 461/2003 on Social Insurance (uses the term "a dependent child" - a person until the accomplishment of compulsory school education, but who has not reached 26 years of age),

- Act No 305/2005 on Social and Legal Protection of Children (distinguishes between " $a$ child" - a person under the age of 18 and "young adult" - a person under the age of 25),

- Act No 406/2011 on Volunteering (defines "youth" as a person aged between 15 and 18).

On the other hand, the United Nations defines youth as the persons between the ages of 15 and 24 years (a period of transition from the dependence of childhood to adulthood's independence and awareness of their independence as members of a community - youth is more a fluid category than a fixed agegroup). ${ }^{2}$ Apart from that, the term "teenager" is often considered synonymous with youth.

The facts above bring us to the conclusion that the definitions as well as the specific age ranges vary, but all the categories of young persons require a targeted specific approach to their protection, re-education and social reintegration.

Moreover, the information presented above was the reason why the members of the Criminal Police Department of the Academy of the Police Force in Bratislava have decided to conduct a research in this field (through the analysis of current situation, the analysis of statistical data, and questioning survey).

\section{Crimes Committed by Minors and Youth in General}

In the Slovak Republic, special provisions on the prosecution of young offenders are in force. For example, a young offender under 15 years of age who, at the time of commission of the criminal offence, has not reached such a mental and moral state so as to be able to recognize its unlawfulness, or to exercise self-restraint shall not be criminally liable for committing the criminal offence. Furthermore, a misdemeanour that meets the elements defined in the Criminal Code shall not be considered as a criminal offence if it has been committed by a young offender. Similarly, if the offender has committed a criminal offence at an age of a young adult, it can be considered a mitigating circumstance which shall be taken into account by the court when imposing the sentence.

2 UNESCO : What do we mean by “youth"? [online], available at: http://www.unesco.org/new/ en/social-and-human-sciences/themes/youth/youth-definition/ (05/12/2015).

[84] NBP • Žurnal za kriminalistiku i pravo 
The specific features of juvenile crime are:

- Perpetrator (age, insufficient criminal experience, etc.);

- Criminal inclination to certain criminal offences (property crime or crime for personal gain and profit);

- Specific modus operandi (in public spaces, in or near the school facilities, unconscious or huge damages, vandalism, etc.)

- Specific factors or determinants (negative family background, bad social situation, alcohol abuse, drug abuse, aggression, weak behavioural control, inadequate solutions of the issues, specific motivation, etc.).

In 2014, the police detected 48,524 cases of general crime and 24,339 cases were successfully solved. According to criminal statistical data 26,963 criminal offenders were prosecuted, whilst 3,004 (11\%) of them were juvenile offenders and $874(3 \%)$ children.

The most frequent type of crime committed by young offenders in 2014 was property crime $(3,422$ criminal offenders) and it was followed by violent crime (510 criminal offenders), other general crime ( 366 criminal offenders), and crime against morality ( 311 criminal offenders). On the other hand, in the past 14 years an enormous decrease in the number of juvenile crimes has been registered (more than $50 \%$ ).

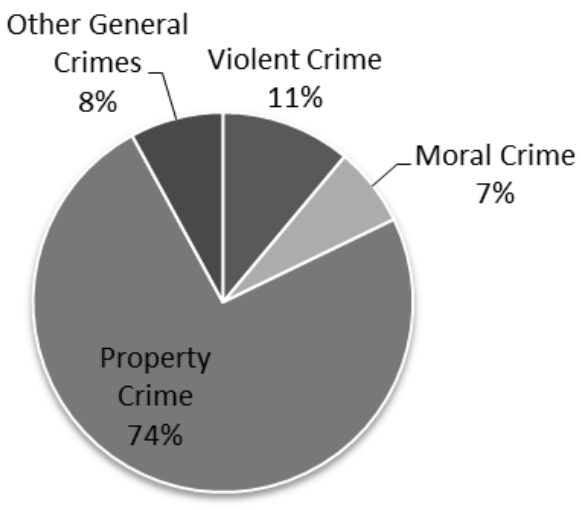

Chart 1 : Proportion of the Main Types of Juvenile Crime in the Slovak Republic, in 2014

Chart 2 shows the comparison and trend in juvenile crime and crime in total in the past fourteen years. From 2001 to 2004, there was a sharp increase in the number of all types of crimes. In 2004, the highest number of crimes (in total) was recorded by the police (131,244 crimes), and since that time the crimes have been steadily decreasing (comparing the last available data by the year 2004; in 2014 - a significant decline by $38 \%$ in the number of cases was recorded). On the other hand, the total fourteen-year rate of juvenile crimes seemed to be constant, but in the analysed period of time an enormous decrease has been recorded (more than $50 \%$ ). The local minimum was recorded in 2013, i.e. 4,563 criminal cases, and a local maximum was reached in 2001, i.e. 9,806 criminal cases. 


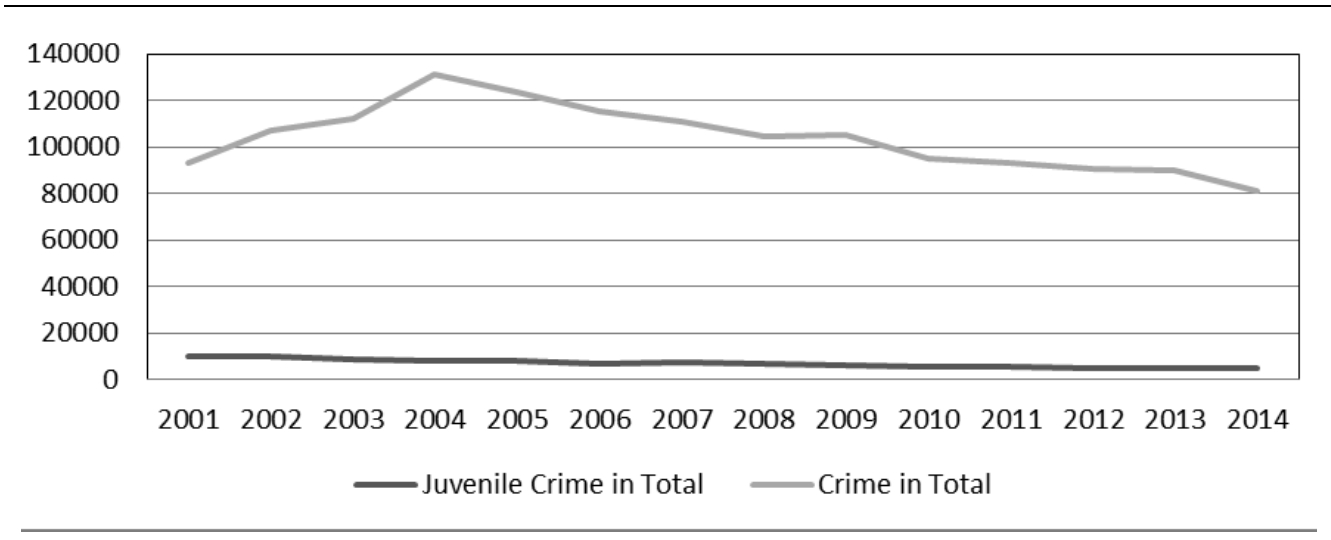

Chart 2: Comparison of the fourteen-year trends of Juvenile Crime and Crime in Total

\section{Violent Crime}

The alarming fact is that violent crime occurs increasingly at elementary schools. The age of criminal offenders varies (in 2014, there were 162 criminal cases committed by very young offenders - children). The most frequent types of violent crime committed by young offenders were (according to 2014 criminal statistic):

- Bodily harm (163 criminal cases),

- Robbery (138 criminal cases),

- Extortion (66 criminal cases),

- Forcible entry into dwelling (36 criminal cases),

- Serious threats (18 criminal cases),

- Assaulting a public official (6 criminal cases),

- Other violent crimes (4 criminal cases),

- Murder (1 criminal case),

- Manslaughter (3 criminal cases),

- Battering a close person and a person entrusted into one' care $(2$ criminal cases).

Violent crimes were often committed by young delinquents in public places, schools, or near school facilities. Mostly, the objects of their interest were money or other items such as mobile phones, computers and other gadgets. A dysfunctional family environment played a significant role and might have been the cause of the commission of the crime (incomplete families, living in foster homes, bad social situation, etc.).

The fourteen-year trend in the rate of youth crime committed by child or juvenile delinquents has been rather stable, as shown in the chart below. 
Comparing the rates and trends of juvenile violent crime and violent crime in total, they are vastly different (from 2001 to 2014, violent crime was visibly decreasing, although in youth violent crime there was a slight decrease).

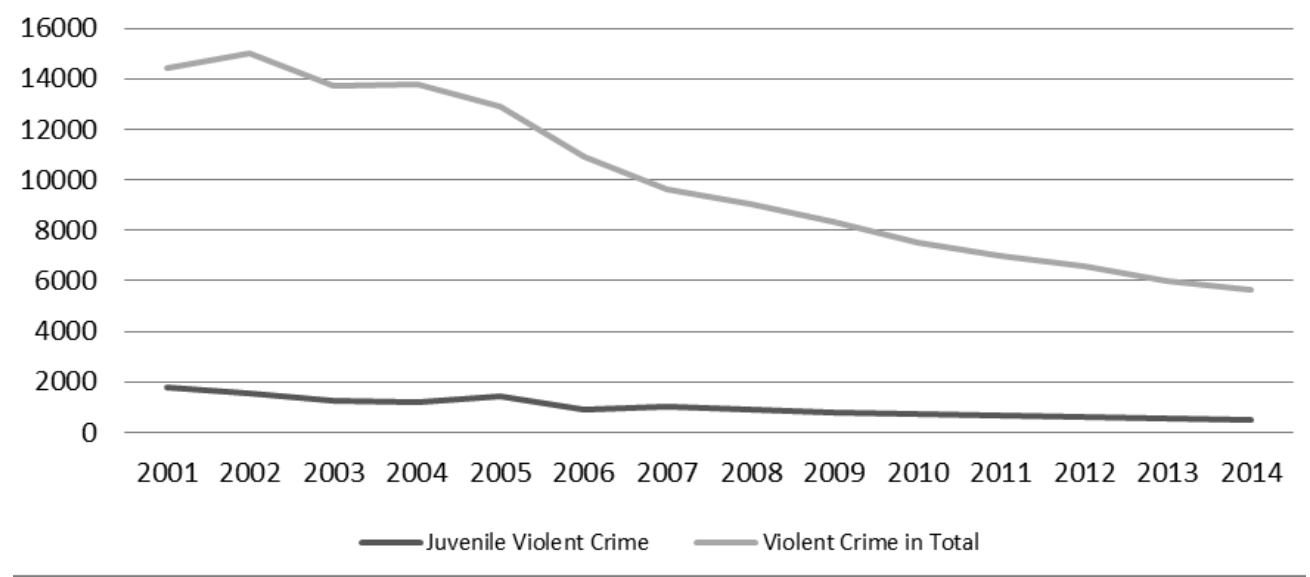

Chart 3: Comparison of the fourteen-year trends of Juvenile Violent Crime and Violent Crime in Total

\section{Crime against Morality}

The crime of young delinquents constituted more than $36 \%$ of the total number of criminal cases against morality in 2014. Bad social and educational environment in the family was considered as the most relevant cause of crime commission, especially in Roma families. According to the police statistical data, the most frequent types of crimes against morality in 2014 were:

- Sexual abuse (278 criminal cases),

- Rape (10 criminal cases),

- Sexual violence (8 criminal cases),

- Possession, manufacturing and dissemination of child pornography (6 criminal cases),

- Disorderly conduct - causing public nuisance through performing a sexual intercourse, indecent exposure or other pathological sexual practices (6 criminal cases).

In comparison to violent crime, the situation in the area of crime against morality was markedly different. In the interval between the years 2001 and 2010, the number of crimes against morality was oscillating; on the other hand, between the years 2010 and 2011, they were on the increase (in 2011, the number of crimes reached its peak); between the years 2011 and 2013 the number of crimes against morality (juvenile crimes against morality and crimes against morality in total) were falling; and finally, in 2014, the number of crimes increased. 


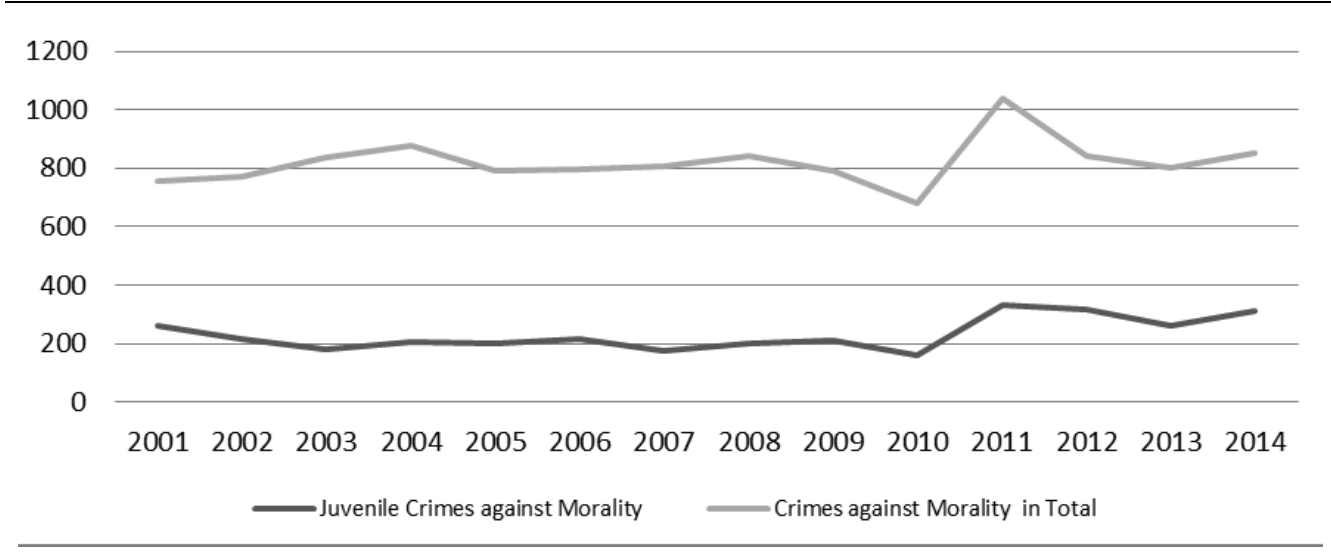

Chart 4: Comparison of the fourteen-year trends of Juvenile Crimes against Morality and Crimes against Morality in Total

\section{Property Crime}

Property crime constitutes the majority of juvenile crimes. Property crimes are often committed by young delinquents in school facilities, electronic shops or storehouses, weekend cottages, houses or flats, etc. Mostly, the objects of their interest are money or other items such as mobile phones, computers and other gadgets. The most frequent types of property crimes that were committed by young people were burglaries ( 879 burglaries were committed by youth in 2014):

- Breaking into a house, a flat, or other accommodation facilities (174 criminal cases),

- Breaking into a weekend cottage (95 criminal cases),

- Breaking into a shop or storehouse (73 criminal cases),

- Breaking into a restaurant (55 criminal cases),

- Breaking into a school (30 criminal cases),

- Breaking into a newsagent (30 criminal cases),

- Breaking into a slot machine, a cash dispenser-ATM, or a safe (9 criminal cases),

- Breaking into a building with antiquities, works of art, and cultural items (7 criminal cases),

- Breaking into other buildings or facilities (406 criminal cases).

The proportions of the main types of juvenile property crimes are shown in Chart 5. Domestic burglaries (as well as unspecified burglaries) were the most frequent type of juvenile property crime which was recorded by the police. 


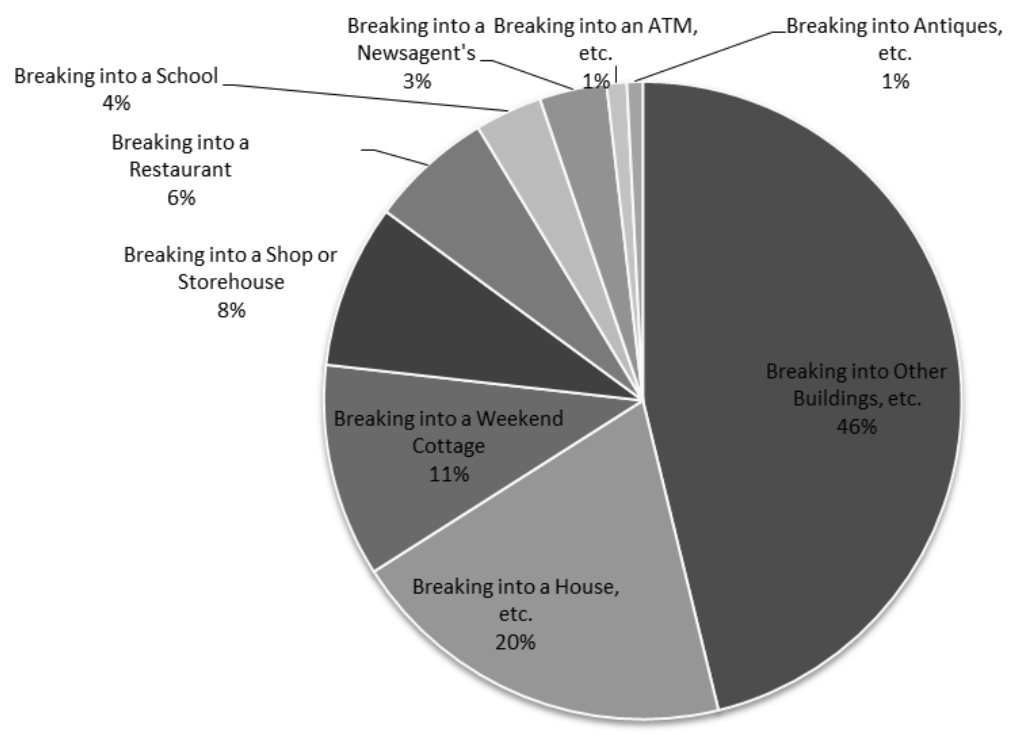

Chart 5: Proportions of the Main Types of Burglaries Committed by Youth, 2014

It is known that young offenders usually take the objects of their desire quite quickly and without long preparation. The analysis of the modus operandi suggests that during the commission of property crimes the offenders enter the closed premises by unauthorised forcing of a lock or by forcible overcoming of different security devices (they use physical power, i.e. smashing with a hand, fist, or some object); they break the window pane, open the window, remove the lock (of the doors), use the inattention of the owner (in pubs, restaurants, etc.), or climb over the fence (in cases of closed doors). According to the available statistical data for 2014, the children and youth often committed thefts such as:

- Theft of personal or collective property from private land (e.g. harvest, wood, fish - 496 criminal cases),

- Theft in a flat and in a house (117 criminal cases),

- Theft of personal or collective property in other premises (305 criminal cases),

- Theft of a motor vehicle ( 132 criminal cases),

- Theft of car components (48 criminal cases),

- Theft of personal property from a car (66 criminal cases),

- Pickpocketing (80 criminal cases),

- Theft of a bike (28 criminal cases),

- Theft of an animal (6 criminal cases),

- Theft of personal property of a passenger ( 2 criminal cases)

- Theft of personal property between colleagues in a workplace ( 9 criminal cases)

- Other theft of personal property from another person (without the use of violence, otherwise it is considered robbery - 65 criminal cases),

- Other thefts (144 criminal cases). 
It is interesting to note that in cases of pickpocketing the juvenile offenders usually look out for drunk or elderly person, and then they watch their victim and wait until they fall asleep or fall down.

The dominant reason for this criminal behaviour is getting money or other valuable things. Their social or family background is typically unfavourable (positive parental role model is absent, imprisoned or jobless parents, recidivist, without paying attention to child development and education, sometimes parents encourage their children to committing crime, etc.). A big problem in Slovakia is that the child and juvenile offenders of property crime often belong to the Roma ethnic group, which is a real challenge for our society. The most frequent objects of their interests in 2014 were: drugstore products, alcohol, tobacco, sweets, chewing gums, watches, electronics, and various tools such as chain saws, brush cutter and clearing saws, computers, and other gadgets.

Apart from that, young offenders frequently destroyed, damaged, or rendered unusable things which belonged to another person, and thus caused damage to another person's property (321 discovered criminal cases in 2014). That may be illustrated on the examples of vandalism, graffiti, smashed glass, demolition of waste containers, traffic signs, car wipers, etc. Many theoreticians and police experts considered this activity as a typical feature of juvenile crime.

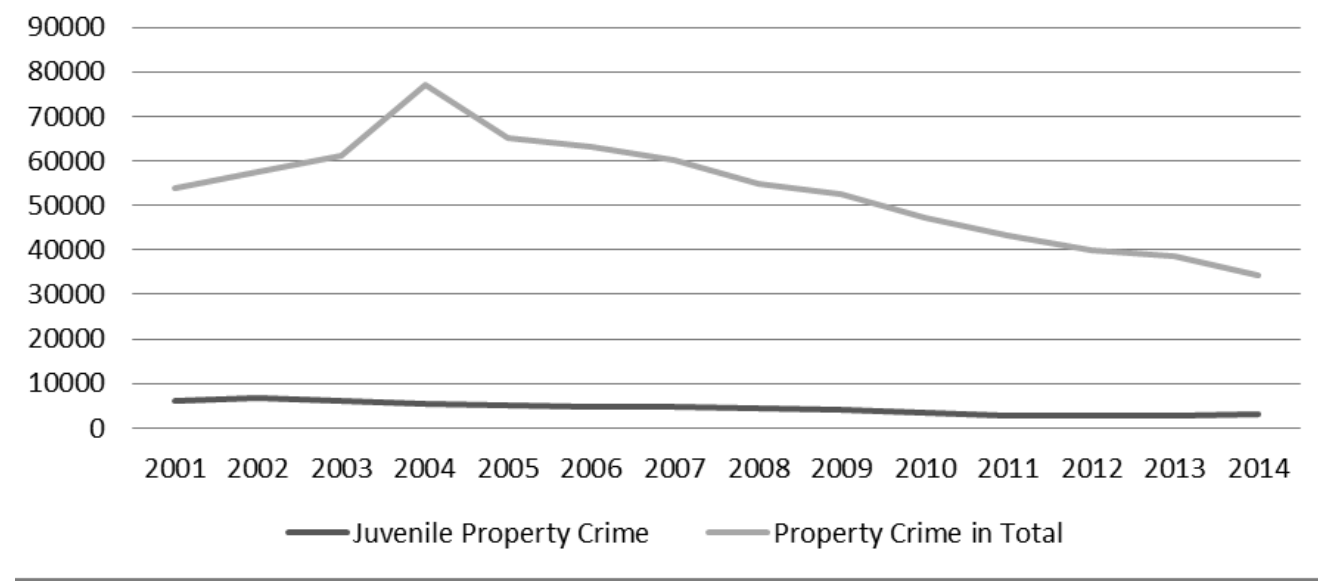

Chart 6: Comparison of the fourteen-year trends of Juvenile Property Crime and Property Crime in Total

The fourteen-year trend of juvenile crime shows that the rate of property crimes committed by young delinquents was rather stable. Comparing the trends of juvenile property crime and total property crime, they are vastly different. From 2001 to 2004, the total property crime rate was increasing, but from 2004 to 2014 , the Chart 6 shows a decline by about $56 \%$ (42,797 criminal cases) in the number of total property crimes recorded by the Slovak Police Force, and in juvenile property crime, there was a fall of 2,066 crimes (39\%). 


\section{Other General Crime}

The number of other general crimes committed by young offenders in 2014 within other general crime in total is 366 cases (from 7,735, it means $4.7 \%$ ). The most frequent type of other general crime committed by young offenders in 2014 was disorderly conduct ( 94 criminal cases of disorderly conduct). The rest of this category of crime in that year included:

- Illicit manufacturing and possession of narcotic and psychotropic substances, poisons or precursors and trafficking in them (21 criminal cases),

- Illicit distribution of drugs (17 criminal cases),

- Unlawful possession of drugs for personal use (71 criminal cases),

- Arson (16 criminal cases),

- Prohibited acquisition and possession of firearms and trafficking in them (13 criminal cases),

- Obstructing the execution of an official decision (43 criminal cases),

- Smuggling of migrants (13 criminal case),

- Other (14 criminal cases).

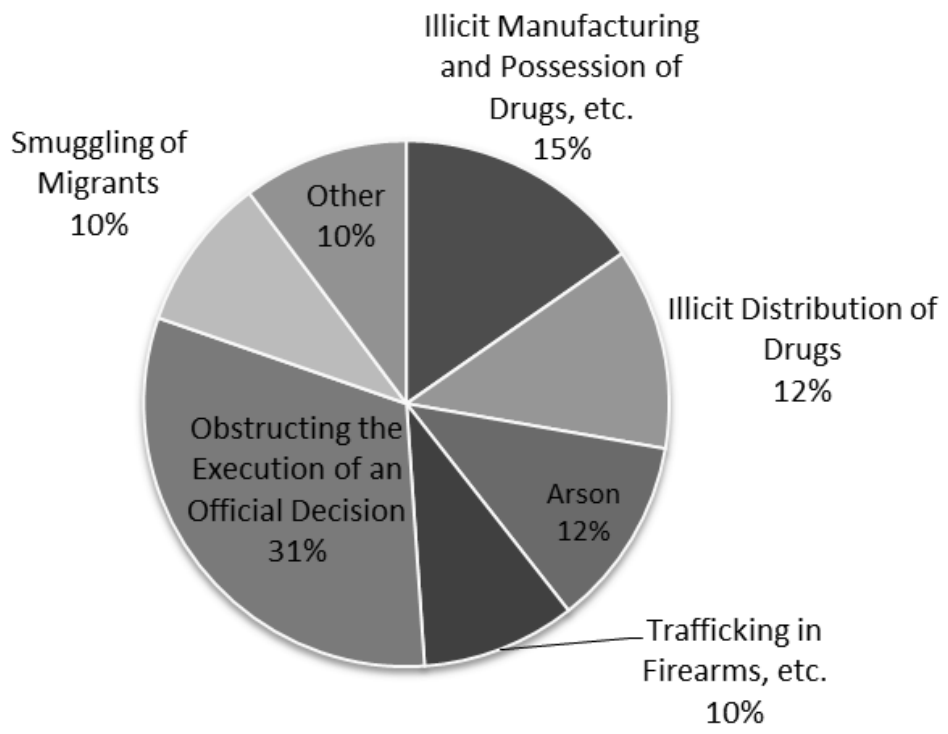

Chart 7: Proportion of Other General Crimes Committed by Youth, 2014

Concerning the disorderly conduct, young offenders repeatedly verbally or physically committed gross indecency or disturbed peace in a place accessible to public. They frequently spread negative information about someone else (insult), polluted public places, destroyed or damaged property of another, caused disturbance in the sleeping hours, and so on. Usually they were under the influence of alcohol or other substances in order to get enough courage to do it. Common reasons for disorderly conduct were to attract or appeal to somebody 
(the opposite sex or people who are about the same age, similar interests, etc.), or sometimes to humiliate, intimidate, and have control over somebody. With regard to drug-related crime, they usually carried only a small amount of drugs ( 1 or 2 fixes) for their personal use, as they tended to claim.

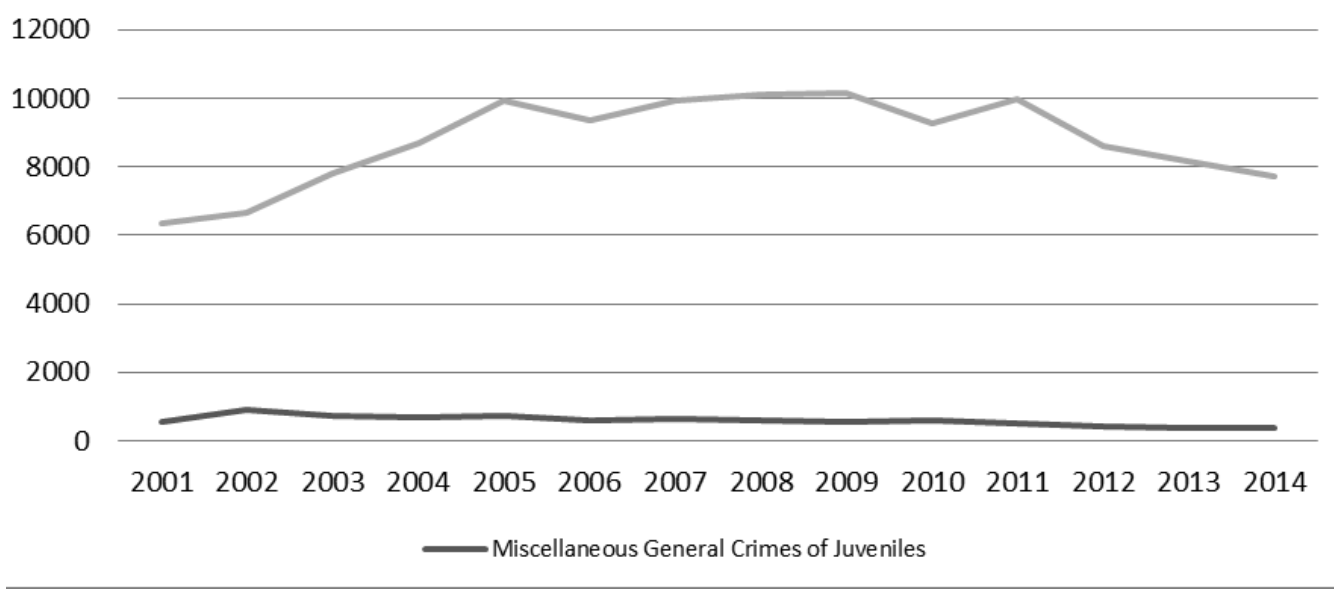

Chart 8: Comparison of the fourteen-year trends of Other General Crimes of Juveniles and Other General Crimes in Total

As can be seen in Chart 8 the fourteen-year trend in youth crime has been rather steady. Comparing the trends of other general crime of juveniles and other general crime in total, we see a big difference. From 2001 to 2005, the number of other general crimes in total increased; then in 2005 other general crimes in total fell considerably (-6\%); between 2006 and 2009 the rate slowly increased again; in 2010 a decline of $(-8 \%)$ and in 2011 a rise of $(+7 \%)$ in the number of crimes was recorded by the police. Moreover, as the chart shows, since 2001 up to now, the downward trend of other general crimes in total has been noticeable $(-23 \%)$, as well as the decline $(-30 \%)$ in other general crimes of the juveniles.

\section{Economic and Environmental Crime}

In 2014, young offenders committed 117 cases of economic and environmental crime (i.e. $0.67 \%$ of the economic and environmental crime in total). As Chart 9 shows, the most frequent type of crime committed by this category of perpetrators was unlawful enjoyment of payment means, electronic money, and other payment card (an offender unlawfully manufactured, altered, imitated, counterfeited or gained possession of payment means, electronic money or other payment card or phone card, or an object of similar function, for the purpose of using it as genuine, or they processed, transported, used or provided it to another for the same purpose). The most typical modus operandi usually consisted of stealing the belongings of another person and then (shortly after the commission of the crime) withdrawing money from an ATM using the stolen credit card. 
The second frequent type of crime committed by youth was poaching (unlawful infringement of hunting regulations by engaging in game hunting and fishing during the closed season, or by using unlawful methods, or by concealing, having in their possession or transferring to themselves or another the game and fish unlawfully caught or found). The most frequent modus operandi was unlawful fishing for personal use, and the typical perpetrator usually came from lower social classes.

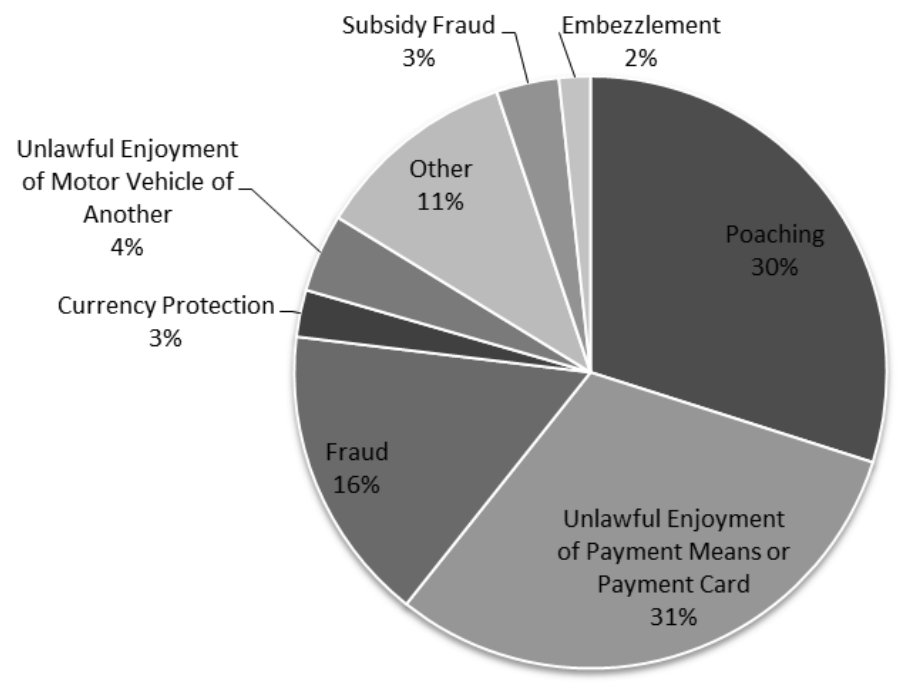

Chart 9: Proportion of Economic and Environmental Crimes Committed by Youth, 2014

Moreover in 2014, juvenile offenders participated in the commission of crimes or committed other types of crime such as bodily harm by negligence $(9 \mathrm{criminal}$ cases), crimes against humanity (8 criminal cases), threat due to intoxication (41 criminal cases), making false alarms or reports (10 criminal cases), and traffic accident-related crimes, i.e. manslaughter, failure to provide assistance (17 criminal cases). The information above indicates that the most frequent type of crime in 2014 was threat due to intoxication (mostly due to alcohol). This crime was prevailingly committed by youth (a young person aged 15-18).

\section{Questionnaire Survey on Current Issues Related to Detection and Clarification of Crimes Committed by Minors and Youth}

Apart from the analysis of the main types of juvenile crimes (presented above), the members of the Criminal Police Department of the Academy of the Police Force in Bratislava have conducted a questionnaire survey on the current issues related to detection and clarification of crimes committed by minors and youth. 
The data collection in the first phase of the scientific research was carried out from March 2015 to June 2015. The sample consisted of 8 respondents (the police officers dealing with juvenile delinquency; limited size sample).

First of all, typical features of juvenile offenders were the main issue. According to the police experts' opinions (80\%), a typical juvenile offender is a lower-middle-class, uneducated (sometimes completed elementary or secondary education) male aged between 14 and 18. On the other hand, there is a certain category of criminal offenders whose parents are solvent and these perpetrators often commit a crime under the influence of drugs or alcohol. Another feature of juvenile offenders is that they are more physically fit than their victims, or frequently the objects of their assault are drunken people, too old, much younger, or weaker people, etc.

A type of crime which is committed by juveniles was another issue. The respondents have agreed on the fact (100\%) that the most frequent type of crime, which is committed by this category of criminal offenders, is property crime (social crimes, street crimes). "Social crimes" are committed by offenders who live in country environment while focusing on poaching, breaking into nonresidential premises, thefts of wood, fruits, and vegetables from private gardens or agricultural cooperatives. The offenders from urban areas prefer the goods from the supermarkets (the objects of their interest are drugstore products, alcohol, tobacco, sweets, chewing gums, watches, electronics, etc.). Apart from that, they frequently commit breaking into a car, breaking into a garage, or mobile phone thefts. From the quantitative aspects, property crimes are followed by extortions, serious threats and intimidations. Among others, the vandalism is the most frequent type of "street crime" committed by minors and youth. On the other hand, the most serious type of crime committed by this type of offenders is drug-related crime, especially in terms of juveniles who live in towns. Possession of narcotic and psychotropic substances, poisons or precursors, and trafficking in them were usually committed by minors and youth whose family's financial situation was better, and on the other hand, minors and youth with worse family's financial situation were often involved in illicit manufacturing and illicit distribution of drugs. The police officers are convinced that the reason is inadequate "parental model or parental role" in their families.

Apart from that we were interested in evaluation of detection and clarification. Most of respondents (80\%) have come to the conclusion that, in general, detection of latent crimes is not very effective. The police officers frequently deal with "reported crimes" (they conduct clarification or investigation); whilst detection is rarely performed in its "pure form", and more than enough is connected with clarification of another crime. A specific "revealing strategy" needs to be used in terms of drug-related crime (with a focus on criminal indicators). In general, insufficient cooperation of persons with the police or law enforcement bodies (especially of parents) contributes to the prevalence of this phenomenon, although clarification (investigation) of juvenile crimes has been evaluated positively.

Moreover, the respondents have been asked about their attitudes towards evaluation of the legal system in the field of fight against juvenile crimes. They are convinced that legal regulation is effective, although punishment seems to be 
inadequate (70\% of asked persons). Slovakia has certain problems with Roma families (bad social and educational environment in the family was considered the most relevant cause in commission of a crime), and sometimes it happens that parents force their children to commit a crime because they do not reach the age of criminal liability. Therefore, children can continue in commission of the crime unless they stay under a negative influence of their parents. Temporary "isolation" of juvenile offenders from a bad social environment (e.g. placement a child in substitute care such as substitute families, foster families, or family type children's home) may bring certain benefits. Apart from that, the respondents have suggested (through the court order) to compel parents of juvenile offenders to participate in seminars or consultations with the experts in psychology, pedagogy, criminology, etc. (how to prevent crime, how to educate a child on salient human values, etc.). Although (according to the opinions of the respondents) the punishment is not generally adequate, increase of "the term of imprisonment" is not necessary. As it was mentioned above, crime prevention of juvenile delinquency, through improvement of their social environment and education, requires a systematic approach of the society.

The analysis of detection and clarification of juvenile crimes (logistics) was another goal of the scientific research. The police experts have presented the opinions that management, organization, competences, coordination of the police activities, and cooperation of the police with the prosecutor offices, trials, and other security services have reached a sufficient level. They have pointed to an insufficient financial support; e.g. visible in cooperation with informants, which is based on financial rewards. Moreover, they have criticized "social pressure" to solve the criminal case very quickly whilst a long-term operative work is not required.

Logically, the possibilities of improvement of the fight against juvenile crime (crime control) were another research ambition. The respondents have suggested:

- Increase in general awareness of crimes or misdemeanours, and their legal consequences, e.g. through preventive activities of the police;

- Increase in number of police officers who deal with minors and youth (prevention, monitoring of risk-juvenile offenders (e.g. at regional police headquarters);

- Improvement of the criminal police officers' local knowledge and knowledge of the persons living in the area;

- Improvement of cooperation with schools, psychologists, foster homes, non-governmental organizations;

- Establishment of a permanent position of "a psychologist for troubled or maladjusted minors and youth" at each school, with a regular and compulsory attendance of troubled or maladjusted minors and youth at seminars or consultations (and/or their parents);

- Participation of troubled or maladjusted minors and youth in "group therapy" (a form of psychosocial treatment) with the persons of the same age or interests;

NBP • Journal of Criminalistics and Law [95] 
- Effective prohibition on selling alcohol and medicines to minors and youth, which may result in decrease of commission of crime under the influence of alcohol or drugs;

- Imposition of the ban on presence of minors in public places after 10 p.m. without adult's accompaniment, which should include sanction for their parents, foster parents, etc.;

- Imposition of the ban on entry of minors into night pubs, bars, disco, etc. where alcohol beverages are served, which should include penalization of a bar owner, or/and suspension or revocation of an alcohol premises licence.

\section{Conclusion}

The author of the study has presented the findings obtained through the analysis of the current situation, statistical data, and the questionnaire survey.

Juvenile crime is the illegal behaviour by children and youth (individuals younger than 18). It is a serious problem although, in Slovakia, in the past 14 years an enormous decrease in the number of crimes has been registered (by more than $50 \%)$. Apart from that, there is a danger that young people could continue committing crime, use more complex or serious modus operandi (preparation, type of weapons or instruments used, criminal cooperation in organized, criminal groups, etc.), and cause more serious effects or consequences (graver damage, injuries or death; less traces or lesser possibilities for revealing their antisocial activities). On the other hand, crime prevention and repression of juvenile crime is the main responsibility of the entire society (including the police, prosecution, and trials). The investigation requires a specific approach by police officers (techniques respecting psychological and emotional world of children), which is very demanding.

When analysing crimes committed against children and youth, it is necessary to mention the negative influence of crime on the emotions and psychology of the child. The potential traumatization can continue for a long period of time, sometimes for the rest of their life and it is connected with social and psychological problems (inability to develop a normal partner relationship and trust people, or negative feelings like fear, anxiety, embarrassment, lacking self-confidence, incredulity, etc.). The children and youth often become victims of morality and violent crime, thus potential traumatization is very likely. The problems of crime detection and further cooperation in investigation are caused by unawareness of the fact that a crime has been committed.

The author of the study is convinced that the presented findings will offer certain open space for discussion and effective control of this negative social phenomenon. 


\title{
References
}

1. Ministry of Interior of the Slovak Republic; Report of the Police Force of the Slovak Republic on Security Situation, 2014.

2. Ministry of Interior of the Slovak Republic; Statistical data of the Ministry of Interior of the Slovak Republic, 2001 - 2014.

3. UNESCO : What do we mean by „youth“? [online], available at: http://www. unesco.org/new/en/social-and-human-sciences/themes/youth/youthdefinition/ (05/12/2015).

\section{IDENTITET TEKUĆIH PROBLEMA U VEZI SA OTKRIVANJEM I RASVETLJAVANJEM MALOLETNIČKOG KRIMINALA U SLOVAČKOJ REPUBLICI}

\author{
Monika Hulova \\ Katedra kriminalističke policije Policijske akademije u Bratislavi \\ Slovačka Republika
}

Sažetak: U ovom radu autorka opisuje situaciju u kojoj se sprovode otkrivanje i rasvetljavanje maloletničkog kriminala u Slovačkoj Republici (analize statističkih podataka, glavni trendovi i problemi). Autorka se bavi odredjenim vrstama kriminala čiji su počinioci maloletnici i omladina, tj. nasilnim kriminalom, kriminalom protiv morala, imovinskim kriminalom, ostalim opštim kriminalom, ekonomskim kriminalom i ekološkim kriminalom. Jedan deo studije donosi rezultate istraživanja (putem upitnika) koje su u policiji sproveli članovi Katedre kriminalističke policije Policijske akademije u Bratislavi. Uprkos činjenici da je autorka došla do zaključka da se čini da borba protiv maloletničke delinkvencije u Slovačkoj Republici jeste efikasna, i dalje je neophodno unaprediti alate za otkrivanje i istragu, jer stopa rasvetljavanja i broj zabeleženih krivičnih dela (koje je zabeležila policija) nisu dovoljni. 